\title{
Benthic in situ respiration in the upwelling area off central Chile
}

\author{
Ronnie Nøhr Glud*, Jens Kristian Gundersen**, Ola Holby***
}

Max Planck Institute for Marine Microbiology, Microsensor Research Group, Celsiusstraße 1, 28359 Bremen, Germany

\begin{abstract}
Benthic $\mathrm{O}_{2}$ uptake rates and $\mathrm{O}_{2}$ microprofiles were measured in the upwelling area off central Chile. Measurements were performed both in situ and in the laboratory on recovered sediment cores. Comparison between the 2 data sets confirmed retrieval and handling artifacts inferred from previous studies. Onboard measurements indicated that the effects were mainly associated with core warming during recovery. Fauna mediated $\mathrm{O}_{2}$ uptake was significant even at abyssal depths and generally in situ $\mathrm{O}_{2}$ uptake rates were higher and showed stronger attenuation with water depth than previous measurements performed in the NE Pacific. However, $\mathrm{O}_{2}$ uptake rates and $\mathrm{O}_{2}$ penetration depths were very similar to measurements performed in the SE Atlantic, and the compiled data sets were approximated by simple exponential equations relating the measurements to water depth. By comparing our total $\mathrm{O}_{2}$ in situ uptake rates to simultaneous measurements of primary production (PP) and new production (NP) of the overlying water column, it was calculated that the benthic mineralization accounted for 13 to $66 \%$ of the PP and for 28 to $92 \%$ of the NP at water depths shallower than $1000 \mathrm{~m}$. At water depths from 1000 to $4000 \mathrm{~m}$, the benthic mineralization equaled 2 to $11 \%$ of the PP and 22 to $38 \%$ of the NP. The benthic mineralization thereby accounted for a significant turnover of organic material even at the abyssal stations. The presented data add to the limited number of in situ deep sea mineralization measurements from the southern hemisphere.
\end{abstract}

KEY WORDS: Benthic mineralization - Oxygen $\cdot$ Landers $\cdot$ In situ $\cdot$ Microsensors

\section{INTRODUCTION}

Organic carbon that settles to the sea floor is mineralized through a complex web of fermentative and respiratory processes, mainly mediated by different populations of microorganisms. Eventually mineralization ceases, and the remaining organic material is buried in the sediment (Berner 1980). Benthic mineralization thereby plays an important role in limiting the burial of carbon in the marine environment. The oxidation of organic carbon to $\mathrm{CO}_{2}$ is balanced by the reduction of available electron acceptors $\mathrm{O}_{2}, \mathrm{NO}_{3}{ }^{-}, \mathrm{Mn}$-oxides, $\mathrm{Fe}$ oxides and $\mathrm{SO}_{4}^{-}$. Although $\mathrm{O}_{2}$ generally may play a

Present addresses:

- Marine Biological Laboratory, University of Copenhagen, Strandpromenaden 5, 3000 Helsingør, Denmark.

E-mail: mblrg@mail.centrum.dk

- National Environmental Research Institute, Vejlsøvej 25, 8600 Silkeborg, Denmark

'-Högskolan Dalarna, Röda Vägen 3, 78188 Borlänge, Sweden minor role in the direct heterotrophic degradation of organic carbon, reduced solutes released during anaerobic degradation are ultimately reoxidized by an equivalent amount of oxygen (Canfield et al. 1993). Therefore common techniques to quantify total benthic mineralization have been the measurements of the total $\mathrm{O}_{2}$ uptake rate (TOU) of the sea floor (e.g. Smith \& Hinga 1983), or alternatively the measurement of the total benthic release of dissolved inorganic carbon (DIC), the ultimate product from organic carbon mineralization (e.g. Anderson et al. 1986).

The region off central Chile is characterized by intense wind-driven upwelling during summer (September-April), which gives rise to some of the highest primary production in the ocean (Fossing et al. 1995). During non-upwelling periods primary production rates are more moderate, but the area is still among the most productive marine environments in the world (Berger et al. 1987) and supports a bountiful fishery. Despite a general interest in the area and numerous investigations in relation to 'El Niño', very few mea- 
surements of the benthic carbon oxidation have been performed in this area (Thamdrup \& Canfield 1996). We here present the first in situ study on benthic exchange and mineralization rates from the upwelling area off Chile. Data are compared to measurements made in the laboratory and to similar studies performed in other regions. The importance of benthic carbon mineralization is discussed in relation to estimates of export production $\left(\mathrm{C}_{\text {org }}\right)$, primary production $(\mathrm{PP})$ and new production (NP) for the area.

\section{MATERIALS AND METHODS}

Logistics. During 2 cruises, a total of 10 stations were investigated. Stns $\mathrm{C} 6$ and $\mathrm{C} 18$ were visited between 12 and 17 March 1994 during the 'Thioploca cruise 1994' with the RV 'Vidal Gomaz' (Fossing et al. 1995). The second cruise took place during the period 11 to 31 May 1995. Here a total of 8 stations were visited. Locations of the individual stations are indicated in Fig. 1 and are listed with station characteristics in Table 1. Sediment cores were recovered for laboratory measurements at all oxic stations, and a profiling lander (Profilur) (Gundersen \& Jørgensen 1990) and a benthic chamber lander (Elinor) (Glud et al. 1994) were successfully deployed at 7 and 9 stations, respectively isee Table 1).

Laboratory measurements. At each station, 4 to 6 sediment cores with a diameter of $9.6 \mathrm{~cm}$ and an

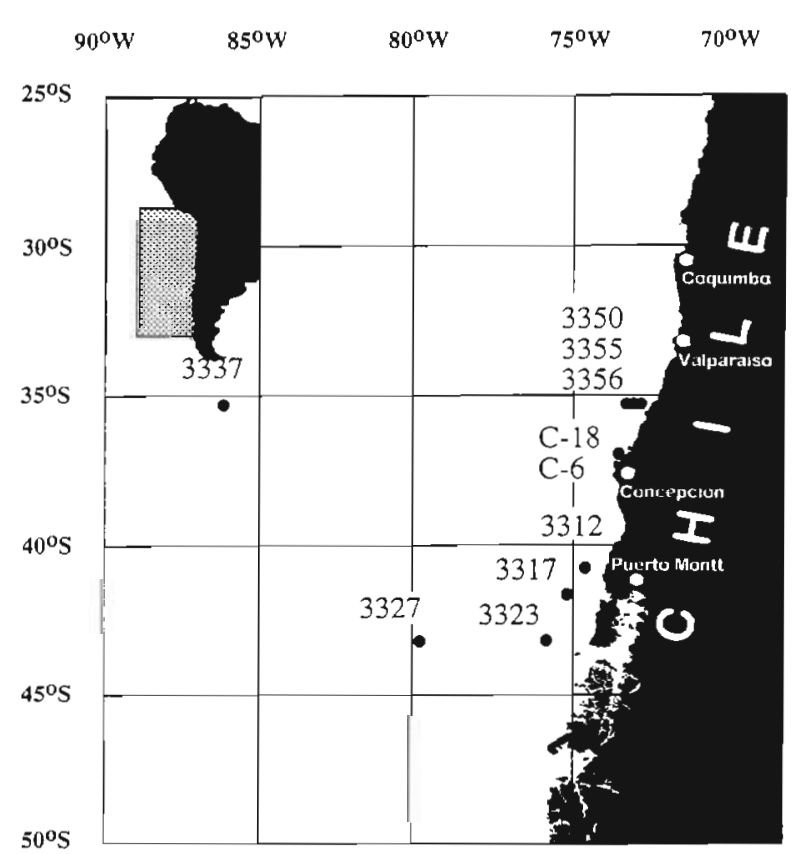

Fig. 1. Study site indicating the positions of the investigated stations approximate length of $30 \mathrm{~cm}$ were recovered by a multiple corer (Barnett 1984). The sediment surface was undisturbed to the extent that small surface structures appeared intact. Immediately after recovery, samples from the overlying water phase were recovered for $\mathrm{O}_{2}$ and DIC determination. Oxygen concentrations were determined by Winkler titration (Strickland \& Parsons 1972), while samples for DIC were stored in $7 \mathrm{ml}$ gastight exetainers (Labco, High Wycombe, UK) spiked with $200 \mu$ saturated $\mathrm{HgCl}_{2}$. The $\mathrm{DIC}$ concentrations were later determined by coulometric titration (VIC, CM 5012) (Johnson et al. 1987).

The sediment cores were submerged in an incubation tank without caps. When cores were from shallow stations $(<100 \mathrm{~m})$, the tank was filled with bottom water prior to the incubations, whereas surface water was used with cores at the deeper stations.

The $\mathrm{O}_{2}$ consumption of surface water was marginal as compared to the sediment $\mathrm{O}_{2}$ consumption rats (not shown). The temperature of the incubation tank was at all stations maintained at the in situ value by a thermostated cooler, while the in situ $\mathrm{O}_{2}$ concentration of the overlying water was ensured through continuous flushing with an air $/ N_{2}$ mixture, regulated from a digital gasmixer (Brooks Instruments). The cores were preincubated for 6 to $12 \mathrm{~h}$ before any measurements were made. Small Teflon-coated magnets were attached to the inner wall of each tube, and their rotation, which was driven by an external magnet, ensured a well-mixed overlying water (Rasmussen \& Jørgensen 1992). The stirring rate gave rise to a diffusive boundary layer (DBL) thickness of approximately $600 \mu \mathrm{m}$ (data not shown).

At each station 3 to $9 \mathrm{O}_{2}$ microprofiles were measured in 3 different sediment cores. The applied $\mathrm{O}_{2}$ sensors were Clark type microelectrodes equipped with a guard cathode and an internal reference (Revsbech 1989). The microelectrodes had outside tip diameters between 10 and $25 \mu \mathrm{m}$, stirring effects $<1 \%$, and a $90 \%$ response time $<1 \mathrm{~s}$ (Revsbech 1989). The position of each microelectrode was controlled by a motor driven micromanipulator, and the sensor signal was recorded by a picoammeter connected to a strip-chart recorder and an A/D-converter which transferred the signals to a PC (Revsbech \& Jørgensen 1986). During profiling, the $\mathrm{O}_{2}$ concentration was recorded at a depth interval of $100 \mu \mathrm{m}$.

The remaining cores were used for whole core incubation. These cores were closed by a butyl-rubber stopper with 2 penetrating glass tubes leaving an internal water height above the sediment interface of 6 to $10 \mathrm{~cm}$. The cores were kept in the incubator throughout the whole sampling program. Samples for $\mathrm{O}_{2}$ determinations $(10 \mathrm{ml})$ were drawn from the enclosed water phase through one tube while the sampling vol- 
Table 1 Characteristics of each sampling site. $L=$ laboratory measurements, $E=$ Elinor successfully deployed, $P=P r o f i l u r$ successfully deployed

\begin{tabular}{|c|c|c|c|c|c|c|}
\hline Station & Latitude & Longitude & $\begin{array}{l}\text { Water depth } \\
\text { (m) }\end{array}$ & $\begin{array}{c}\text { Bottom water } \\
\mathrm{O}_{2}(\mu \mathrm{M})\end{array}$ & $\begin{array}{c}\text { Bottom water } \\
\text { temp. }\left({ }^{\circ} \mathrm{C}\right)\end{array}$ & Cast \\
\hline $\mathrm{C} 6$ & $36^{\circ} 37.3^{\prime} \mathrm{S}$ & $73^{\circ} 00.6^{\prime} \mathrm{W}$ & 34 & 0 & 11.4 & $\mathrm{EP}$ \\
\hline C18 & $36^{\circ} 31.4^{\prime} \mathrm{S}$ & $73^{\circ} 08.2^{\prime} \mathrm{W}$ & 87 & 0 & 11.7 & EP \\
\hline GeoB 3312 & $40^{\circ} 59.5^{\prime} \mathrm{S}$ & $74^{\circ} 20.1^{\prime} \mathrm{W}$ & 606 & 209 & 5.5 & LE \\
\hline GeoB 3317 & $42^{\circ} 01.9^{\prime} \mathrm{S}$ & $75^{\circ} 18.1^{\prime} \mathrm{W}$ & 3012 & 147 & 1.8 & LE \\
\hline GeoB 3323 & $43^{\circ} 13.0^{\prime} \mathrm{S}$ & $76^{\circ} 00.0^{\prime} \mathrm{W}$ & 3459 & 161 & 1.8 & LEP \\
\hline GeoB 3327 & $43^{\circ} 14.0^{\prime} \mathrm{S}$ & $79^{\circ} 87.0^{\prime} \mathrm{W}$ & 3533 & 170 & 1.7 & LE \\
\hline GeoB 3337 & $35^{\circ} 15.0^{\prime} \mathrm{S}$ & $86^{\circ} 00.0^{\prime} \mathrm{W}$ & 4079 & 182 & 1.7 & LP \\
\hline GeoB 3350 & $35^{\circ} 15.3^{\prime} \mathrm{S}$ & $73^{\circ} 25.2^{\prime} \mathrm{W}$ & 2470 & 153 & 1.8 & LEP \\
\hline GeoB 3355 & $35^{\circ} 13.0^{\prime} \mathrm{S}$ & $73^{\circ} 06.7^{\prime} \mathrm{W}$ & 1445 & 136 & 2.7 & LEP \\
\hline GeoB 3356 & $35^{\circ} 13.1^{\prime} \mathrm{S}$ & $73^{\circ} 12.2^{\prime} \mathrm{W}$ & 580 & 176 & 5.6 & LEP \\
\hline
\end{tabular}

ume was replaced by water from the incubation tank through the second tube (the dilution was later corrected for). The samples were recovered in gastight glass syringes and Winkler reagents were added directly to the syringes. Six samples were recovered from each core at an evenly spaced time interval. The $\mathrm{O}_{2}$ concentrations were never allowed to decrease by more than $35 \%$ of the initial concentration during the 3 to $75 \mathrm{~h}$ long incubations before the incubation was ended. The $\mathrm{O}_{2}$ concentrations of the samples were later determined by titration.

In situ measurement. The 2 benthic landers, Profilur and Elinor, were deployed in order to measure $\mathrm{O}_{2}$ microprofiles and benthic exchange rates in situ. Both landers worked as independent vehicles and after deployment they sank towards the seafloor at a speed of approximately $35 \mathrm{~m} \mathrm{~min} \mathrm{~m}^{-1}$. The Profilur was equipped with 4 to $7 \mathrm{O}_{2}$ microelectrodes with the same characteristics as the sensors applied in the laboratory. One hour after landing at the sea floor, the Profilur lowered the sensor array in increments of $100 \mu \mathrm{m}$ and at each depth the signals of all sensors were recorded and stored (Gundersen \& Jørgensen 1990). After a total traveling distance of $20 \mathrm{~cm}$, the sensors were retracted and a bottom water sample was collected for sensor calibration. The obtained microprofiles contained 2 inherent calibration points, the constant reading in the bottom water and the constant low reading in the anoxic sediment.

The benthic chamber lander, Elinor, implanted a central respiration chamber during landing and after a resting period of $1 \mathrm{~h}$; incubation was initiated by lidclosure (Glud et al. 1994). The water phase was stirred by a central impeller which gave rise to an average DBL thickness of approximately $520 \mu \mathrm{m}$ (Glud et al. 1995a). The $\mathrm{O}_{2}$ concentration was measured continuously by minielectrodes (Glud et al. 1995a). During the incubation, 5 to 10 water samples of $50 \mathrm{ml}$ were retracted from the overlying water phase at predefined time intervals. The water was replaced by water from outside the chamber and the dilution was later corrected for. Ten $\mathrm{ml}$ of each sample were stored in gastight glass ampoules for later $\mathrm{O}_{2}$ determination while the rest was stored in $50 \mathrm{ml}$ plastic syringes. At the end of the incubation a scoop closed beneath the chamber and the incubated sediment was recovered together with the lander. On deck the water samples for $\mathrm{O}_{2}$ and DIC were treated as described above. The $\mathrm{O}_{2}$ determination was used for subsequent sensor calibration. Exchange rates of DIC were only measured during incubations with a presumed high activity or when logistics allowed long deployments. The lander recovered sediment was sieved through a mesh screen of $1 \mathrm{~mm}$; the macrofauna was collected, stored in $70 \%$ ethanol and later sorted into taxa. The dry weight and the weight loss following ignition at $560^{\circ} \mathrm{C}$ for $24 \mathrm{~h}$ was determined for each group of macrofauna.

It has been shown that central stirring of benthic chambers creates radial pressure gradients, which can initiate an advective porewater transport in permeable sediments (Huettel \& Gust 1992a, Glud et al. 1996). However, the sediments we investigated were fine grained and highly impermeable. Enhanced flushing of empty burrows caused by the stirring cannot be completely excluded. However, the maximal pressure gradients in the chamber at the applied stirring rate was $0.048 \mathrm{~Pa} \mathrm{~cm}^{-1}$ (Glud et al. 1995a), which only marginally can affect flushing of U-shaped burrows (Huettel \& Gust 1992b).

Calculations. From the obtained microprofiles it was possible to determine the upper boundary of the DBL as the intersection point between the extrapolated linear $\mathrm{O}_{2}$ gradient in the DBL and the constant $\mathrm{O}_{2}$ value in the overlying water (see Fig. 3 ['Results'], Jørgensen \& Revsbech 1985). Since the position of the sediment surface typically was indicated by a distinct break in the profile (Glud et al. 1995b), the DBL thickness could be determined. The diffusive $\mathrm{O}_{2}$ uptake (DOU) was calcu- 
lated from measured microprofiles by applying Fick's first law of diffusion: $-\mathrm{DOU}=D_{0}(\delta C / \delta z)$, where $D_{0}$ is the diffusion coefficient in water and $C$ is the solute concentration at a given depth $(z)$ within the DBL. The temperature corrected $D_{0}$ values for $\mathrm{O}_{2}$ were derived from Broecker \& Peng (1974) and Li \& Gregory (1974). Fig. 3D demonstrates how the DBL, the position of the sediment surface and the concentration slope within the DBL were defined. The average specific $\mathrm{O}_{2}$ consumption was calculated by dividing the DOU with the thickness of the oxic zone. Total fluxes of DIC and $\mathrm{O}_{2}$ (TOU) were calculated by linear regression of solute concentrations as a function of incubation time accounting for the enclosed water volume.

\section{RESULTS}

The $\mathrm{O}_{2}$ concentration of the bottom water varied among the investigated stations. At the 2 shallowest stations the bottom water (BW) was fully anoxic, while the $\mathrm{O}_{2}$ concentration varied between 136 and $209 \mu \mathrm{M}$ at the remaining stations (Table 1 ). Values obtained by Winkler titration on water recovered by the landers or the 'multiple corer' never deviated by more than $5 \%$ from data recorded by a CTD (data not shown). Measurements performed during the 'SCORPIO'-cruises at stations in immediate vicinity of some of the deeper stations investigated in this study (GeoB-3323, 3327, $3350,3355,3356)$ resulted in $\mathrm{BW} \mathrm{O}_{2}$ concentrations which differed by no more than $7 \%$ from our measurements (Reid 1973, Warren 1973).

At each of the 2 anoxic stations the chamber lander was deployed twice. At Stn C6 the measured DIC release rates were 210 and $116 \mathrm{mmol} \mathrm{m}^{-2} \mathrm{~d}^{-1}$, while the rates were 31.4 and $25.0 \mathrm{mmol} \mathrm{m}^{-2} \mathrm{~d}^{-1}$ at Stn $\mathrm{C}-18$ (Table 2). The variability in exchange rate at each site reflects the sediment heterogeneity. Massive, but het- erogeneous, occurrence of the colorless sulfur bacteria Thioploca spp. and Beggiatoa spp. was apparent at both stations, and the total bacterial biomass was found to be 700 and $1200 \mathrm{~g} \mathrm{~m}^{-2}$ (wet weight) at sites close to $\mathrm{C} 6$ and $\mathrm{C} 18$, respectively (Fossing et al. 1995, Schulz et al. 1996). However, despite sediment variability the in situ DIC release rates, matched depth integrated carbon oxidation rates determined by bag incubations techniques within a factor of 2 at those same stations (Thamdrup \& Canfield 1996).

At each of the remaining stations the chamber lander was deployed once. The in situ TOU varied from $-15.7 \mathrm{mmol} \mathrm{m} \mathrm{m}^{-2} \mathrm{~d}^{-1}$ at Stn GeoB 3312 to a minimum value of $-1.4 \mathrm{mmol} \mathrm{m}^{-2} \mathrm{~d}^{-1}$ at Stn GeoB 3327 (Table 2). The in situ DIC release rate co-varied with TOU, and the (DIC release/TOU)-ratio varied between 1.0 and 1.5 at the investigated stations (Table 2). This demonstrates that the TOU and the DIC release rates resulted in comparable benthic mineralisation rates. Both TOU measured in the laboratory and in situ correlated with water depth (Table 2), but generally the laboratory values overestimated the in situ values at the deepest stations, while they were lower at the more shallow stations (Table 2). Fig. 2 presents examples of incubation measurements obtained in situ.

The profiling lander was deployed once per station. In general in situ and laboratory microprofiles were similar, and only at the deepest station (where both measurements were successfully performed) did the profiles differ significantly (Table 2, Fig 3). Here the $\mathrm{O}_{2}$ penetration in the laboratory only accounted for $30 \%$ of the in situ value, while the laboratory DOU was approximately 3 times higher than the corresponding in situ value (Table 2).

The in situ $\mathrm{O}_{2}$ uptake rates and $\mathrm{O}_{2}$ penetration depths were comparable to similar measurements performed in the SE Atlantic (Glud et al. 1994). In both data sets the difference between TOU and DOU was

Table 2. Total exchange of oxygen (TOU) and dissolved inorganic carbon (DIC); diffusive oxygen uptake (DOU) and oxygen penetration $\left(\mathrm{O}_{2}\right.$ pen.) depth measured in situ and in the laboratory. Standard deviations are included. Values in parentheses show the number of replicates

\begin{tabular}{|c|c|c|c|c|c|c|c|}
\hline Station & $\begin{array}{l}\text { TOU_in situ } \\
\left(\mathrm{mmol} \mathrm{m}^{-2} \mathrm{~d}^{-1}\right)\end{array}$ & $\begin{array}{c}\text { DIC-in situ } \\
\left(\mathrm{mmol} \mathrm{m} \mathrm{m}^{-2} \mathrm{~d}^{-1}\right)\end{array}$ & $\begin{array}{l}\text { DOU_in situ } \\
\left(\mathrm{mmol} \mathrm{m} \mathrm{m}^{-2} \mathrm{~d}^{-1}\right)\end{array}$ & $\begin{array}{c}\mathrm{O}_{2} \text { pen.- }- \text { in situ } \\
(\mathrm{mm})\end{array}$ & $\begin{array}{l}\text { TOU-in lab } \\
\left(\mathrm{mmol} \mathrm{m} \mathrm{m}^{-2} \mathrm{~d}^{-1}\right)\end{array}$ & $\begin{array}{c}\text { DOU_in lab } \\
\left(\mathrm{mmol} \mathrm{m}^{-2} \mathrm{~d}^{-1}\right)\end{array}$ & $\begin{array}{c}\mathrm{O}_{2} \text { pen-in lab } \\
(\mathrm{mm})\end{array}$ \\
\hline $\mathrm{C}-6$ & $0.0 \pm 0.0(2)$ & $163 \pm 47(2)$ & $0.0 \pm 0.0(6)$ & $0.0 \pm 0.0(6)$ & - & - & - \\
\hline$C-18$ & $0.0 \pm 0.0(2)$ & $28.2 \pm 3.2(2)$ & $0.0 \pm 0.0(6)$ & $0.0 \pm 0.0(6)$ & - & - & - \\
\hline GeoB 3312 & -15.7 & 18.3 & - & - & $-10.9 \pm 1.8(3)$ & $-12.3 \pm 1.9(7)$ & $1.0 \pm 0.4(7)$ \\
\hline GeoB 3317 & -3.9 & - & - & - & $-2.1 \pm 0.5(3)$ & $-2.6 \pm 0.7(9)$ & $7.8 \pm 1.1(9)$ \\
\hline GeoB 3323 & -2.8 & - & $-0.9 \pm 0.3(6)$ & $37.8 \pm 2.9(6)$ & $-4.0 \pm 1.0(3)$ & $-2.9 \pm 0.8(11)$ & $11.4 \pm 1.8(11)$ \\
\hline GeoB 3327 & -1.4 & - & - & - & $-2.6 \pm 0.3(3)$ & - & - \\
\hline GeoB 3337 & - & - & $-0.3 \pm 0.1(5)$ & $129.7 \pm 10.2(5)$ & $-1.9 \pm 0.5(3)$ & - & - \\
\hline GeoB 3350 & -2.8 & 4.1 & $-2.4 \pm 1.0(5)$ & $12.6 \pm 1.6(5)$ & $-3.7 \pm 0.6(3)$ & $-2.6 \pm 0.2(5)$ & $7.1 \pm 2.1(5)$ \\
\hline GeoB 3355 & -3.6 & 3.7 & $-2.8 \pm 0.7(5)$ & $11.1 \pm 3.4\{5\}$ & $-4.5 \pm 0.8(3)$ & $-2.4 \pm 0.5(3)$ & $7.5 \pm 1.5(3)$ \\
\hline GeoB 3356 & -9.7 & 10.6 & $-4.9 \pm 0.9(6)$ & $6.5 \pm 1.4(6)$ & $-7.7 \pm 0.7(3)$ & $-4.6 \pm 0.1(3)$ & $6.6 \pm 0.1(3)$ \\
\hline
\end{tabular}


significant at the shallow fauna-rich stations, but converged at the deeper stations (Fig. 4A). The compiled data set was fitted by 2 simple exponential equations expressing TOU and DOU as a function of water depth $(z)$; TOU $=2.76 \mathrm{e}^{-0.57 \times 10^{-3} z}\left(\mathrm{r}^{2}=0.65\right)$ and DOU $=$ $1.93 \mathrm{e}^{-0.55 \times 10^{-3} z}\left(\mathrm{r}^{2}=0.88\right)$ (Fig. 4A). The $\mathrm{O}_{2}$ penetration depth in both studies increased exponentially with water depth as the average specific $\mathrm{O}_{2}$ consumption rate decreased by almost 3 orders of magnitude at water depths from 500 to $5000 \mathrm{~m}$ (Fig. 4B,C). The strong correlations between water depth and (1) benthic $\mathrm{O}_{2}$ uptake rates, (2) $\mathrm{O}_{2}$ penetration depth and (3) the specific $\mathrm{O}_{2}$ consumption rate indicate that the sedimentation of organic carbon to the seafloor was the key variable regulating the benthic $\mathrm{O}_{2}$ uptake in both regions. Data did not correlate well with bottom water $\mathrm{O}_{2}$ concentration (not shown).
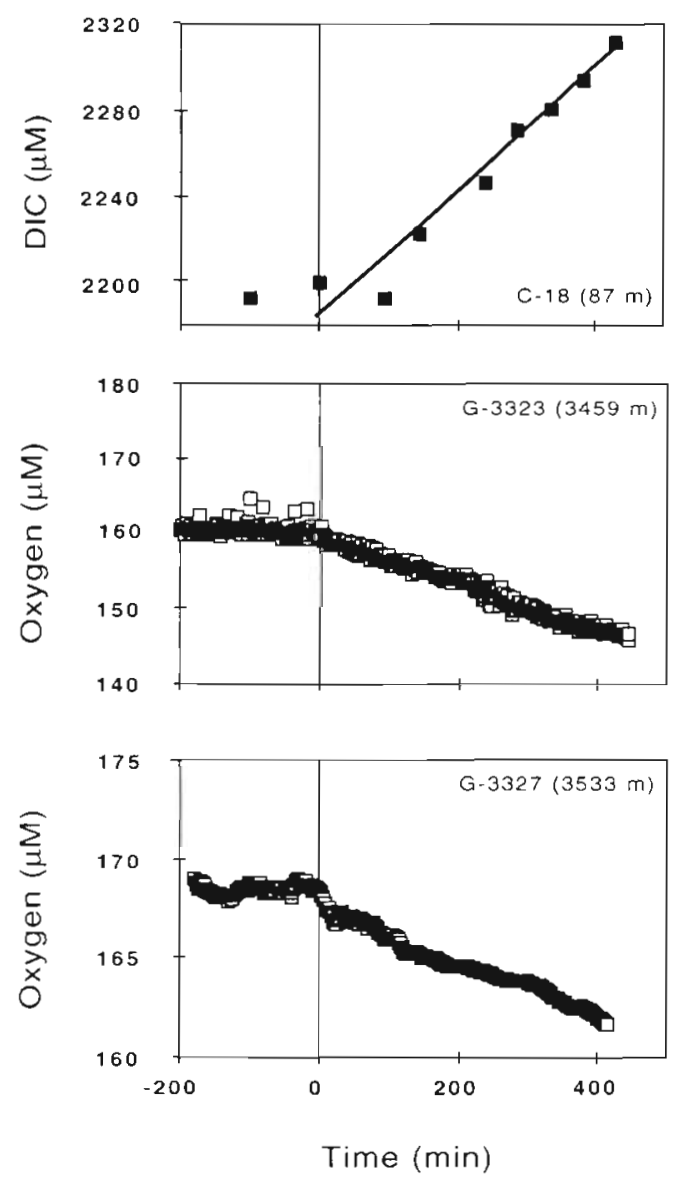

Fig. 2. Concentration of DIC and $\mathrm{O}_{2}$ as measured during 3 separate deployments of the benthic chamber lander. The selected data represent a very shallow station, the deepest station, and the deepest station where both landers were successfully deployed. Data collected during descent are omitted and the vertical line (time 0 ) indicates lid closure. The water column heights in the chamber during the 3 incubations were $7.4,6.2$ and $12.1 \mathrm{~cm}$, respectively
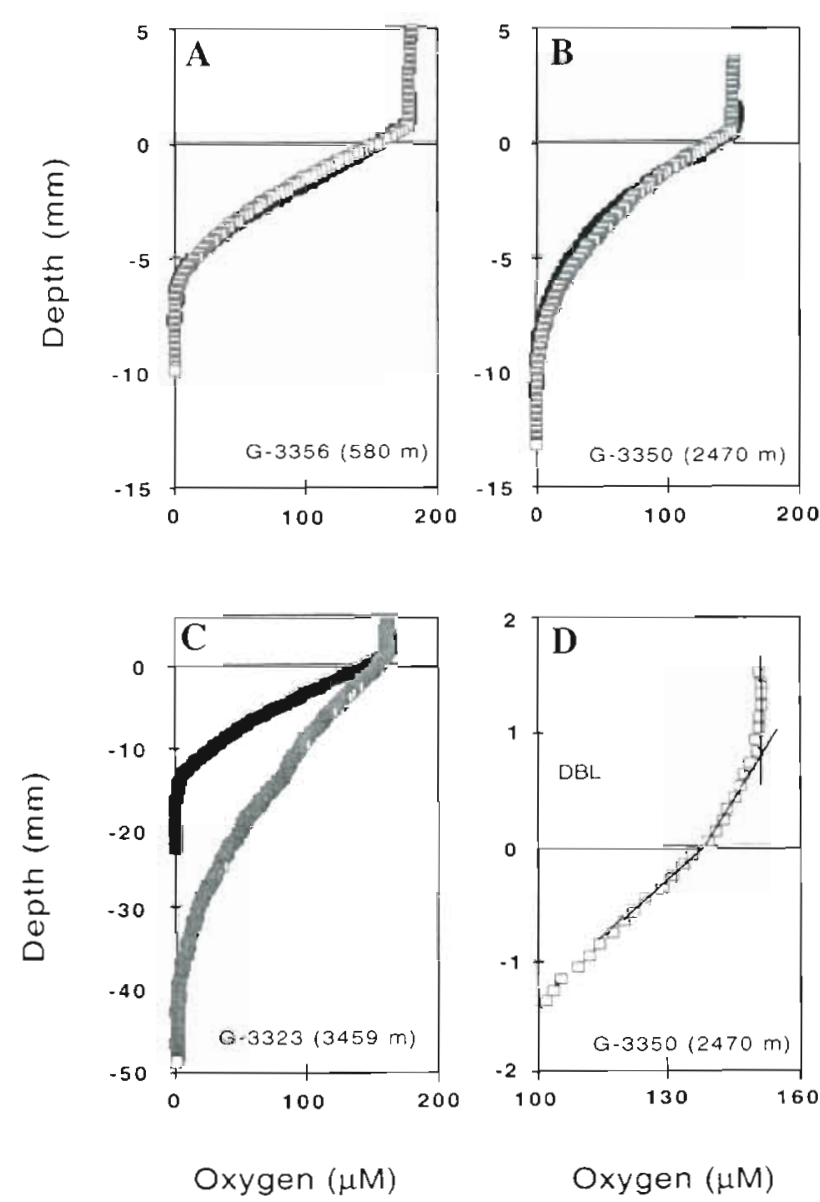

Fig. 3. (A-C) Individual oxygen microprofiles measured in situ (gray squares) and in the laboratory (black squares) (D) Expanded view of the measuring points at the interface of the in situ profile shown in (B). Horizontal line indicates the position of sediment surface (depth 0). DBL: diffusive boundary layer

\section{DISCUSSION}

\section{$\mathrm{O}_{2}$ uptake measured by the various techniques}

This study's comparison between in situ and laboratory data confirm that retrieval and handling artifacts also inferred in previous studies (Devol \& Christensen 1993, Glud et al. 1994, Aller et al. 1998). At shallow stations, laboratory and in situ microprofiles were similar, while they differed at the deepest investigated station (Table 2, Fig. 3). In a previous study it was demonstrated that at water depths $>2000 \mathrm{~m}$ in situ microprofiles exhibited significantly deeper $\mathrm{O}_{2}$ penetration and lower DOU values as compared to microprofiles measured in recovered sediment cores (Glud et al. 1994). The effect was a function of water depth and the maximum difference was observed at approximately $5000 \mathrm{~m}$ water depth where the $\mathrm{O}_{2}$ penetration in the 

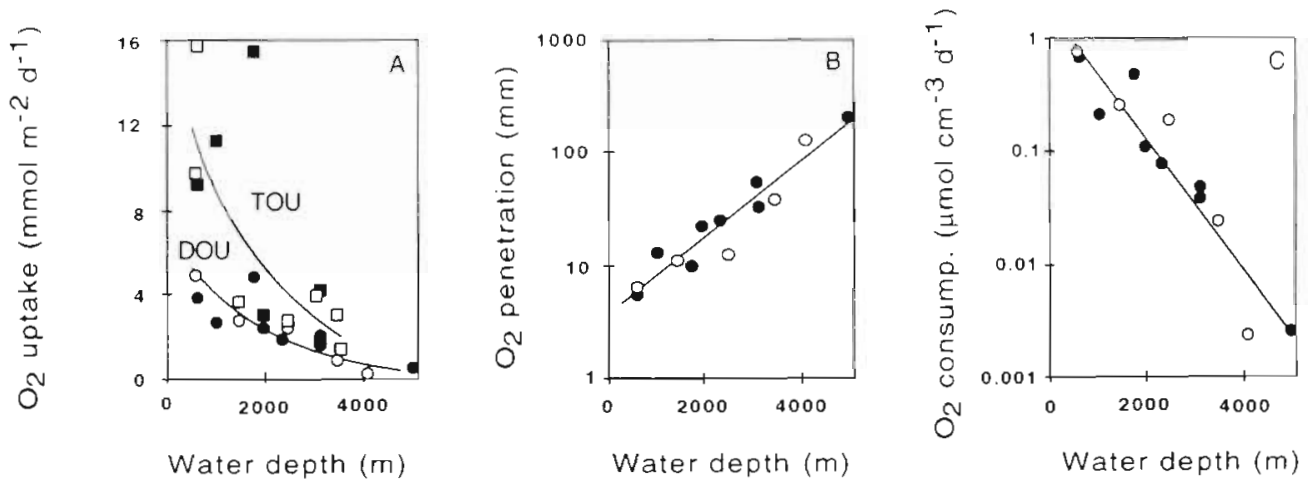

Fig. 4. Total $\mathrm{O}_{2}$ uptake squares (TOU, squares) and the diffusive $\mathrm{O}_{2}$ uptake (DOU, circles) as a function of the water depth. Filled symbols represent data measured in the Benguela upwelling area of the SE Atlantic (Glud et al. 1994), while open symbols represent data from the present study. The compiled data set was fitted to 2 exponential equations describing the DOU and TOU as a function of water depth. $(\mathrm{B})$ and $(\mathrm{C})$ represent the $\mathrm{O}_{2}$ penetration depth $(\mathrm{OP})$ and the average specific $\mathrm{O}_{2}$ consumption $\left(\mathrm{O}_{2}\right.$ consump.) calculated from microprofiles obtained in the present study (O) and by Glud et al. (1994) ( $\bullet$ ). The compiled data set was fitted by $O P=1.32 \mathrm{e}^{0.77 \times 10^{-3} z}\left(\mathrm{r}^{2}=0.91\right)$ and $\mathrm{O}_{2} \operatorname{con}=0.62 \mathrm{e}^{1.33 \times 10^{-3} z}\left(\mathrm{r}^{2}=0.89\right)$, respectively

laboratory only accounted for $25 \%$ of the in situ value while the laboratory DOU value was 3.5 times higher than the corresponding in situ value (Glud et al. 1994). These findings are confirmed by the present study (Table 2, Fig. 3),

The recovery of sediment cores from $3500 \mathrm{~m}$ water depth to the warmer surface waters combined with the onboard handling prior to preincubation caused the temperature in the center of the core to increase from 1.7 to $7.1^{\circ} \mathrm{C}$ (data not shown). Consecutive microprofile measurements in such a sediment core placed at in situ temperature in the incubation chamber reflected elevated DOU values which gradually approached the in situ rate (Fig. 5). A parallel core which initially was

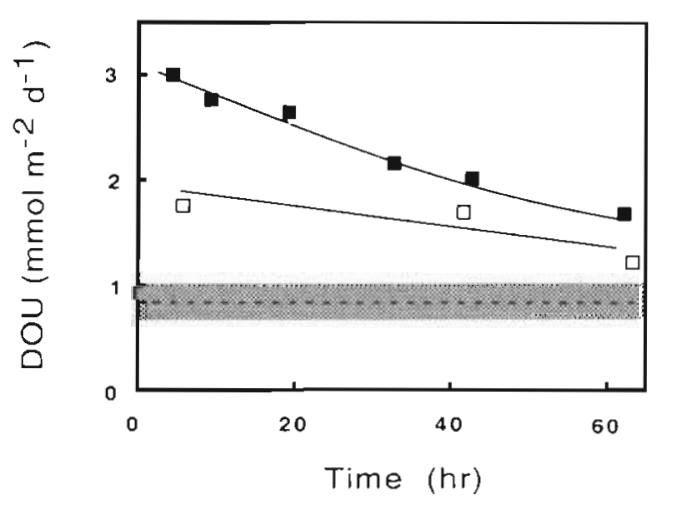

Fig. 5. Temporal development of the diffusive $\mathrm{O}_{2}$ uptake (DOU) in 2 recovered sediment cores. The cores were recovered at time 0 min. Broken horizontal line indicates the average DOU measured in situ, and the shaded bar the SD of the measurement. Lines following the data points were handdrawn (the data are partly redrawn from a Danish report, Gundersen et al. 1995) allowed to reach a temperature of $20^{\circ} \mathrm{C}$ (reached after $45 \mathrm{~min}$ at room temperature) prior to placement in the incubation tank at in situ temperatures showed a stronger but similar response. The data demonstrate that for abyssal sediments, a transient rise in temperature during recovery alters the oxygen consumption rate in recovered sediment cores and that in such cases long preincubation periods at in situ temperature $\left(>60 \mathrm{~h}\right.$ ) are required in order to reestablish in situ $\mathrm{O}_{2}$ conditions.

We speculate that heating, potentially in combination with release of labile organic carbon from lysed psychro- or barophilic microbiota, stimulates the microbial activity of recovered sediment cores. Placed at in situ temperature the activity decreases; however, the diffusive supply of $\mathrm{O}_{2}$ towards the deeper sediment layers which have been depleted in $\mathrm{O}_{2}$ during the transient heating require a preincubation period. For shallow water depths, higher in situ temperature and lower $\mathrm{O}_{2}$ penetration depth shortens the required preincubation period, and for stations at water depths $<2000 \mathrm{~m} 6$ to $12 \mathrm{~h}$ was sufficient in the present study (Table 2). Such a recovery effect also explains the relatively high TOU rates measured in sediments recovered from the abyssal stations (Table 2). At the shallow fauna-rich stations the laboratory determined TOU, however, generally underestimated the in situ values (Table 2). As previously suggested, we ascribe this to inactivation of recovered fauna and more representative inclusion of larger infauna species in the larger in situ incubation chamber $\left(896 \mathrm{~cm}^{2}\right)$ as compared to the smaller sediment cores applied in the laboratory $\left(68 \mathrm{~cm}^{2}\right)$ (Devol \& Christensen 1993, Glud et al. 1994, 1998). Thereby laboratory determined TOU rates are affected by 2 opposing effects: temporary heating which increases the $\mathrm{O}_{2}$ uptake and exclusion or inactivation of 
Table 3. Amount of benthic fauna and fauna mediated oxygen uptake (TOU-DOU), porosity and organic carbon values for the upper $5 \mathrm{~mm}$ in the investigated sediments. LOI = loss on ignition. $\mathrm{nm}=$ not measured

\begin{tabular}{|c|c|c|c|c|c|}
\hline Station & $\begin{array}{l}\text { Water depth } \\
\text { (m) }\end{array}$ & $\begin{array}{c}\text { Fauna } \\
\text { LOI }\left(\mathrm{g} \mathrm{m}^{-2}\right)\end{array}$ & $\begin{array}{l}\text { TOU-DOU } \\
\left(\mathrm{mmol} \mathrm{m}^{-2} \mathrm{~d}^{-1}\right)\end{array}$ & $\begin{array}{l}\text { Porosity } \\
\text { (vol/vol) }\end{array}$ & $\begin{array}{c}\text { Organic C } \\
(\%)\end{array}$ \\
\hline C6 & 34 & 5.1 & $\mathrm{~nm}$ & 0.88 & 6.31 \\
\hline C18 & 87 & 3.0 & $\mathrm{~nm}$ & 0.93 & 4.43 \\
\hline GeoB 3312 & 606 & 9.4 & $3.4 \pm 1.9^{\mathrm{d}}$ & 0.87 & $\mathrm{~nm}$ \\
\hline GeoB 3317 & 3012 & 4.1 & $1.3 \pm 0.7^{\mathrm{a}}$ & 0.91 & 1.50 \\
\hline GeoB 3323 & 3459 & 2.4 & $1.9 \pm 0.3$ & 0.83 & $\mathrm{~nm}$ \\
\hline GeoB 3327 & 3533 & 1.9 & $\mathrm{~nm}$ & 0.86 & $\mathrm{~nm}$ \\
\hline GeoB 3337 & 4079 & - & $\mathrm{nm}$ & 0.84 & 0.63 \\
\hline GeoB 3350 & 2470 & 2.2 & $0.4 \pm 1.0$ & 0.90 & 2.73 \\
\hline GeoB 3355 & 1445 & 8.2 & $0.8 \pm 0.7$ & 0.86 & 3.04 \\
\hline GeoB 3356 & 580 & 16.2 & $4.8 \pm 0.9$ & 0.89 & $\mathrm{~nm}$ \\
\hline
\end{tabular}

macrofauna which decreases the $\mathrm{O}_{2}$ uptake. In relation to water depth the in situ TOU was more scattered than the DOU (Fig. 4A); this is most likely caused by patchy distribution of benthic fauna.

Simultaneous in situ measurements of DOU and TOU were only successfully performed at 4 stations. The difference between TOU and DOU, which is a measure of the fauna-mediated $\mathrm{O}_{2}$ uptake (Archer \& Devol 1992), varied from 0.4 to $4.8 \mathrm{mmol} \mathrm{m}^{-2} \mathrm{~d}^{-1}$ at the investigated stations. The values generally correlated to the amount of fauna recovered by the Elinor chamber (Table 3 ). The macrofauna was at all stations dominated by polychaetes, both in numbers and weight, and the benthos mediated $\mathrm{O}_{2}$ uptake was probably caused largely by burrow irrigation, exposing otherwise anoxic sediment to $\mathrm{O}_{2}$. The faunamediated $\mathrm{O}_{2}$ uptake was higher than that deduced from comparable measurements performed off central California (Jahnke et al. 1990) but generally comparable to measurements performed off Namibia (Glud et al. 1994). These observations suggest that macrofaunal activity may indeed be significant and consequently of importance for regional C cycling in deep sea sediments located in regions of continental upwelling.

\section{High $\mathrm{O}_{2}$ uptake of the southern upwelling areas}

Our in situ $\mathrm{O}_{2}$ uptake rates for the SE Pacific are higher than previous in situ measurements taken at comparable water depths in the North and NE Pacific (Smith \& Baldwin 1984, Jahnke \& Jackson 1987, Jahnke et al. 1990, Archer \& Devol 1992, Reimers et al. 1992, Smith et al. 1994, 1997). To our knowledge no in situ measurements from the South Pacific have previously been published. The presented data match measurements taken in the Benguela upwelling area (Fig.
6), and both data sets show stronger attenuation with water depth compared to measurements in upwelling areas of the Northern Pacific and Atlantic (Fig. 6, Glud et al. 1994). Data extracted from a recently constructed global map of estimated benthic $\mathrm{O}_{2}$ consumption rates at water depths less than $1000 \mathrm{~m}$ (Jahnke 1996) underestimated our measurements in both upwelling areas especially at shallow depths as did a predictive equa-

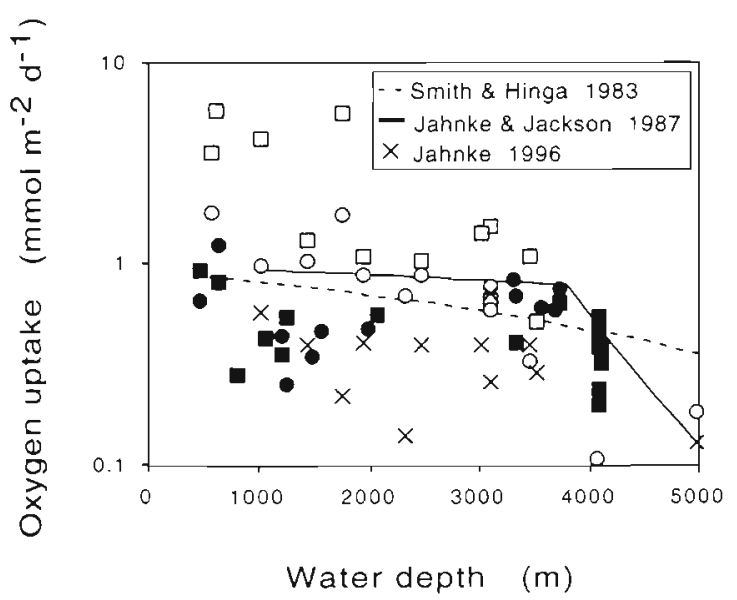

Fig. 6. $\mathrm{O}_{2}$ uptake rates as a function of water depth from a number of different studies and predictive equations. Open symbols represent measurements made in the SE Atlantic (Glud et al. 1994) and the SE Pacific (TOU = squares, DOU = circles), while closed symbois represent data obtained in the NE Pacific in 3 other studies (Jahnke et al. 1990, Archer \& Devol 1992, Smith et al. 1994). Data points within an extremely strong $\mathrm{O}_{2}$ minimum zone and at water depth $<500 \mathrm{~m}$ are omitted. Two predictive equations from the NE Pacific relating the TOU to water depth are included together with values for all investigated stations as extracted from Jahnke (1996). For the predictive equation of Smith \& Hinga (1983) we applied the regional yearly primary production as accumulated by Berger et al. (1987) 
Table 4. Benthic mineralisation (BM) in percent of (1) the yearly export production from the photic zone (Exp P) (derived from Hebbeln et al. in press). (2) primary production (PP) and (3) new production (NP) at the investigated stations (data supplied by 0 . Ulloa unpubl.). The latter 2 parameters were measured during the same period and at the same locations as those at which the $\mathrm{BM}$ measurements were obtained. $\mathrm{nm}=$ not measured

\begin{tabular}{|c|c|c|c|c|}
\hline Station & Water depth (m) & $\mathrm{BM} \%$ of $\operatorname{Exp} P$ & $\mathrm{BM} \%$ of $\mathrm{PP}$ & $B M \%$ of $N P$ \\
\hline C6 & 34 & - & 66.4 & 91.5 \\
\hline C18 & 87 & - & 18.9 & 28.1 \\
\hline GeoB 3312 & 606 & - & 41.0 & $n m$ \\
\hline GeoB 3317 & 3012 & 41 & 11.1 & 24.1 \\
\hline GeoB 3323 & 3459 & 29 & 8.8 & 24.5 \\
\hline GeoB 3327 & 3533 & 15 & 10.5 & 38.2 \\
\hline GeoB 3337 & 4079 & $3^{a}$ & $1.7^{\circ}$ & $22.4^{\mathrm{d}}$ \\
\hline GeoB 3350 & 2470 & 29 & $\mathrm{~nm}$ & $\mathrm{~nm}$ \\
\hline GeoB 3355 & 1445 & 38 & 4.4 & $\mathrm{~nm}$ \\
\hline GeoB 3356 & 580 & - & 13.4 & 45.0 \\
\hline
\end{tabular}

tion for the Pacific proposed by Smith \& Hinga (1983) (Fig. 6). A predictive equation of Jahnke \& Jackson (1987), which was generated for water depth $>1000 \mathrm{~m}$ for the NE Pacific, gave a reasonable fit to our data, but still tended to underestimate the measurements at water depth $<3000 \mathrm{~m}$ (Fig. 6). Another model, based on data from the North Pacific, expresses the $\mathrm{O}_{2}$ flux as a function of the bottom water $\mathrm{O}_{2}$ concentration and the organic carbon percentage of the surficial sediment (Cai \& Reimers 1995) and also underestimated our compiled data set (not shown). (Surface organic carbon was only obtained at 6 stations off Chile [Table 3], but at all stations off Namibia.)

Our observations confirm that eastern upwelling areas of the Atlantic and the Pacific have substantially higher $\mathrm{O}_{2}$ uptake than the central or western nonupwelling regions (Jahnke \& Jackson 1987, Jahnke 1996) and suggest that the southern upwelling areas are characterized by higher $\mathrm{O}_{2}$ consumption rates as compared to investigated northern upwelling regions. However, comparison of $\mathrm{O}_{2}$ uptake rates obtained in various regions is complicated by local, seasonal and interannual variation.

A 2 yr sediment trap study in the SE Pacific $\left(30^{\circ} 00^{\prime} \mathrm{S}\right.$, $73^{\circ} 11^{\prime} \mathrm{W}$ ) in the vicinity of our research area estimated the annual organic carbon export from the photic zone

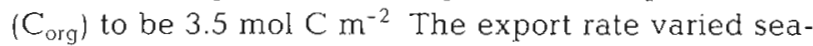
sonally with maximum values of about $29 \mathrm{mmol} \mathrm{C} \mathrm{m}^{-2}$ $\mathrm{d}^{-1}$ in September 1993 and minimum values around $1.7 \mathrm{mmol} \mathrm{C} \mathrm{m} \mathrm{m}^{-2} \mathrm{~d}^{-1}$ in May-June the following year (Hebbeln et al. in press). Our rates for the deeper sites were obtained in May 1995, and the $C_{\text {org }}$ export estimated in the same seasonal period in 1994 by Hebbeln et al. (in press) (between 1.5 and $2 \mathrm{mmol} \mathrm{C} \mathrm{m}^{-2} \mathrm{~d}^{-1}$ ) could not account for the benthic mineralization we measured (see Table 2). Potential reasons for the gap between the 2 data sets are (1) the site investigated by Hebbeln et al. (in press) is not representative for our stations (2) interannual variation, or (3) temporal displacement between water column production and benthic mineralization. In situ measurements have demonstrated that benthic $\mathrm{O}_{2}$ uptake responds to the seasonal input of organic carbon even at abyssal depths but that the response is significantly dampened (e.g. as the export of $\mathrm{C}_{\text {org }}$ varied by a factor of 10 to 15 , the benthic $\mathrm{O}_{2}$ uptake varied by less than a factor of 2.5 ) (Smith et al. 1994, 1997). In more oligotrophic waters in situ measurements have demonstrated seasonally invariable TOU rates despite the fact that the export of $\mathrm{C}_{\text {org }}$ fluctuated by a factor of 4 (Sayles et al. 1994). If we assume that our in situ TOU measurements represent the yearly average benthic mineralization rate, then 3 to $41 \%$ of the annual exported $\mathrm{C}_{\text {org }}$ estimated by Hebbeln et al. (in press) is mineralized in the sediment (stations $>1000 \mathrm{~m}$ water depth), leaving 97 to $59 \%$ for water column respiration and permanent burial (Table 4).

During the 2 cruises reported here PP and NP of organic carbon were determined at the same locations and at the same time as we performed our measurements (O. Ulloa unpubl.). The measurements were performed by carbon isotope incubation and estimated from the nitrogen requirement during a $24 \mathrm{~h}$ cycle 10 . Ulloa unpubl.). The fraction of the PP mineralized in the sediment generally inversely correlated with water depth and reached a maximum value of $66 \%$ at $34 \mathrm{~m}$ water depth while a minimum value of $2 \%$ was obtained at the deepest site of $4079 \mathrm{~m}$ (Table 4). For most stations the measured NP rates were higher than the export of production measured during the same seasonal period in 1994 at the site investigated by Hebbeln et al. (in press). For the abyssal stations 25 to $38 \%$ of the new production of organic carbon was min- 
eralized in the sediment, while a maximum of $92 \%$ of NP was mineralized in the sediment at the $34 \mathrm{~m}$ station (Table 4). These measurements represent the conditions in May 1995, and it is difficult to evaluate to what extent our measurements resolve the temporal fluctuations in the coupling between NP and TOU. Nevertheless, our calculations strongly indicate that the benthic mineralization in the upwelling areas of the SE Pacific, even at abyssal depths, is responsible for recycling a significant fraction of the organic carbon leaving the photic zone.

Acknowledgements. We are grateful to Henrik Fossing, Victor Ariel Gallardo and Bo Barker Jorgensen for organizing the Thioploca expedition 1994. We are thankful for the competent cruise leading of Gerold Wefer and Dierk Hebbeln during the RV 'Sonne' cruise 102. Additionally, we would like to thank the captains and crews of RV 'Sonne' and RV 'Vidal Gomez' for their assistance during the cruises. Anni Glud, Gabriele Eickert and Anja Eggers are thanked for skillful construction of the applied microsensors. Osvaldo Ulloa is thanked for supplying the unpublished data presented in Table 4 and Rick Jahnke for supplying the data extracted from the map presented in Jahnke (1996). Clare Reimers is thanked for commenting upon an earlier version of the manuscript. This work was supported by the Max Planck Society and the 'Deutsche Forschungsgemeinschaft' (special project of the German Science Foundation 'The South Atlantic in the late quaternary: Reconstruction of material budget and current system'). In the writing process R.N.G. was supported by the Danish National Research Council (SNF) and the support is gratefully acknowledged.

\section{LITERATURE CITED}

Aller RC, Hall POJ, Rude PD, Aller JA (1998) Biogeochemical. heterogeneity and suboxic diagenesis in hemipelagic sediments of the Panama Basin. Deep-Sea Res 45:133-165

Anderson LG, Hall POJ, Iverfeldt $\AA$, Rutgers van der Loeff $M$, Sundby B, Westerlund SFG (1986) Benthic respiration measured by total carbonate production. Limnol Oceanogr 31:319-329

Archer D, Devol A (1992) Benthic oxygen fluxes on the Washington shelf and slope: a comparison of in situ microelectrode and chamber flux measurements. Limnol Oceanogr $37: 614-629$

Barnett PRO, Watson J, Connelly D (1984) A multiple corer for taking virtually undisturbed samples from shelf, bathyal and abyssal sediments. Oceanol Acta 7:399-408

Berger WHK, Fisher K, Lai C, Wu G (1987) Ocean productivity and organic carbon flux. Part I. Overview and maps of primary production and export production. Scripps Institution of Oceanography (SIO) Reference, University of California, La Jolla, San Diego, p 30-87

Berner RA (1980) Early diagenesis: a theoretical approach Princeton University Press, Princeton

Broecker WS, Peng TH (1974) Gas exchange rates between air and sea. Tellus 26:21-35

Cai WJ, Reimers CE (1995) Benthic oxygen concentration and core top organic carbon content in the deep northeast Pacific Ocean. Deep-Sea Res 42:1681-1699

Canfield DE, Jargensen BB, Fossing H, Glud RN, Gundersen
JK, Thamdrup B, JW Hansen, Nielsen LP, Hall POJ (1993) Pathways of organic carbon oxidation in three continental margin sediments. Mar Geol 113:27-40

Devol HA, Christensen JP (1993) Benthic fluxes and nitrogen cycling in sediments of the continental margin of the eastern North Pacific. J Mar Res 51:345-372

Fossing $\mathrm{H}$, Gallardo VA, Jørgensen BB, Hüttel M, Nielsen LP, Schulz H, Canfield DE, Forster S, Glud RN, Gundersen JK, Küver J, Ramsing NB, Teske $A$, Thamdrup $B$, Ulloa $O$ (1995) Concentration and transport of nitrate by the matforming sulphur bacterium Thioploca. Nature 374 $713-715$

Glud RN, Gundersen JK, Jorgensen BB, Revsbech NP, Schulz HD (1994) Diffusive and total oxygen uptake of deep-sea sediments in the eastern South Atlantic Ocean: in situ and laboratory measurements. Deep-Sea Res 41:1767-1788

Glud RN, Gundersen JK, Revsbech NP, Jorgensen BB, Hüttel $M$ (1995a) Calibration and performance of the stirred flux chamber from the benthic lander Elinor. Deep-Sea Res 42 $1029-1042$

Glud RN, Jensen K, Revsbech NP (1995b) Diffusivity in surficial sediments and benthic mats determined by use of a combined $\mathrm{N}_{2} \mathrm{O}-\mathrm{O}_{2}$ microsensor. Geochim Cosmochim Acta 59:231-237

Glud RN, Forster S, Huettel M (1996) Influence of radial pressure gradients on solute exchange in stirred benthic chambers. Mar Ecol Prog Ser 141:303-311

Glud RN, Holby H, Hoffmann F, Canfield DE (1998) Benthic mineralization and exchange in Arctic sediments (Svalbard). Mar Ecol Prog Ser 173:237-251

Gundersen JK, Jargensen BB (1990) Microstructure of diffusive boundary layers and the oxygen uptake of the sea floor. Nature 345:604-607

Gundersen JK, Glud RN, Jørgensen BB (1995) Havbundens iltomsætning. Havforskning Miljøstyrelsen 57:1-155

Hebbeln D, Marchant M. Wefer G (in press) Seasonal variations of the particle flux in the Peru-Chile current at $30^{\circ} \mathrm{S}$ under 'normal' and under El Niño conditions. Deep-Sea Res II

Huettel M, Gust G (1992a) Solute release mechanisms from confined sediment cores in stirred benthic chambers and flume flows. Mar Ecol Prog Ser 82:187-197

Huettel M, Gust G (1992b) Impact of bioroughness on interfacial solute exchange in permeable sediments. Mar Ecol Prog Ser 89:253-267

Jahnke RA (1996) The global ocean flux of particulate organic carbon: areal distribution and magnitude. Global Biogeochem Cycles 10:71-88

Jahnke RA, Jackson GA (1987) Role of sea floor organisms in oxygen consumption in the deep North Pacific Ocean Nature 329:621-623

Jahnke RA, Reimers CE, Craven DB (1990) Intensification of recycling of organic matter at the sea floor near ocean margins. Nature 348:50-54

Johnson KM, Sieburth JM, Williams PJL, Brandstrom L (1987) Coulometric total carbon dioxide analysis for marine studies: automation and calibration Mar Chem 21:117-133

Jørgensen BB, Revsbech NP (1985) Diffusive boundary layers and oxygen uptake of sediments and detritus. Limnol Oceanogr 30:111-122

Li YH, Gregory S (1974) Diffusion of ions in deep-sea sediments. Geochim Cosmochim Acta 38:703-714

Rasmussen H, Jørgensen BB (1992) Microelectrode studies of seasonal oxygen uptake in a coastal sediment: role of molecular diffusion. Mar Ecol Prog Ser 81:289-303

Reid JL. (1973) The transpacific hydrographic sections at Lats $43^{\circ} \mathrm{S}$ and $28^{\circ} \mathrm{S}$ : the SCORPIO Expedition-III. Upper water 
and a note on the southward flow at mid-depth. Deep-Sea Res 20:39-49

Reimers CE, Jahnke RA, McCorkle DC (1992) Carbon fluxes and burial rates over the continental slope and rise off central California with implications for the global carbon cycle. Global Biogeochem Cycles 6:199-224

Revsbech NP (1989) An oxygen microelectrode with a guard cathode. Limnol Oceanogr 34:474-478

Revsbech NP, Jørgensen BB (1986) Microelectrodes and their use in microbial ecology. In: Marshall KC (ed) Advances in microbial ecology, 9. Plenum, New York, p 293-352

Sayles FL, Martin WR, Deuser WG (1994) Response of oxygen demand to particulate organic carbon supply in the deep sea, Bermuda. Nature 371:686-689

Schulz H, Jargensen BB, Fossing H, Ramsing NB (1996) Community structure of filamentous, sheath-building sulfur bacteria, Thioploca spp., off the coast of Chile. Appl Environ Microbiol 62:1855-1862

Smith KL Jr, Baldwin RJ (1984) Seasonal fluctuations in deepsea sediment community oxygen consumption: central and eastern North Pacific. Nature 307:624-625

Editorial responsibility: Otto Kinne (Editor),

Oldendorf/Luhe, Germany
Smith KL Jr, Hinga KR (1983) Sediment community respiration in the deep sea. In: Rowe GT (ed) The sea, Vol 8. Wiley and Sons, New York, p 331-370

Smith KL Jr, Kaufmann RS, Baldwin RJ (1994) Coupling of near-bottom pelagic and benthic processes at abyssal depths in the eastern North Pacific Ocean. Limnol Oceanogr 39:1101-1118

Smith KL Jr, Glatts RC, Baldwin RJ, Beaulieu SE, Ulman AH, Horn RC, Reimers CE (1997) An autonomous, bottom-transecting vehicle for making long time-series measurements of sediment community oxygen consumption to abyssal depths. Limnol Oceanogr 42: 1601-1612

Strickland JD, Parsons TR (1972) A practical handbook of seawater analysis, 2nd edn. Bull Fish Res Bd Can 167

Thamdrup B, Canfield DE (1996) Pathways of carbon oxidation in continental margin sediments off Chile. Limnol Oceanogr 41:1629-1650

Warren BA (1973) The transpacific hydrographic sections at Lats. $43^{\circ} \mathrm{S}$ and $28^{\circ} \mathrm{S}$ : the SCORPIO Expedition-II. Deep water. Deep-Sea Res 20:9-38

Submitted: December 8, 1998; Accepted: April 30, 1999

Proofs received from author(s): August 11, 1999 